\title{
PENGEMBANGAN PERANGKAT PEMBELAJARAN BERBASIS MASALAH KONTEKSTUAL UNTUK MENINGKATKAN KEMAMPUAN METAKOGNISI SISWA SEKOLAH DASAR
}

\author{
Mohammad Faizal Amir ${ }^{1 *}$, Mahardika Darmawan Kusuma W. ${ }^{2}$ \\ 1,2Jurusan PGSD, Universitas Muhammadiyah Sidoarjo \\ *faizal.amir@umsida.ac.id
}

Diterima: November 2017. Disetujui: Desember 2017. Dipublikasikan: Januari 2018

\begin{abstract}
ABSTRAK
Penelitian ini bertujuan untuk mengembangkan perangkat pembelajaran berbasis masalah kontekstual untuk meningkatkan kemampuan metakognisi siswa sekolah dasar. Proses pengembangan perangkat terdiri dari tahap pendefinisian (define), perancangan (design), dan pengembangan (develop). Perangkat yang dikembangkan meliputi rencana pelaksanaan pembelajaran, lembar kerja, tes metakognisi, dan kuesioner kemampuan metakognisi pada materi Kelipatan Persekutuan Terkecil (KPK) dan Faktor Persekutuan Terbesar (FPB). Teknik pengumpulan data menggunakan validasi ahli, observasi, kuesioner, dan tes. Subjek penelitian adalah siswa kelas lima SDN Kalitengah I Tanggulangin Sidoarjo. Hasil penelitian menunjukkan bahwa perangkat pembelajaran berbasis masalah kontekstual yang dikembangkan berkualitas baik. Hal ini dapat dilihat dari keterlaksanaan pembelajaran berkatergori baik, aktivitas siswa berkategori baik, respon metakognisi siswa berkategori positif, ketuntasan hasil belajar metakognisi siswa secara klasikal tercapai. Kemampuan metakognisi siswa menunjukkan hal yang lebih baik dalam hal kesadaran merencanakan, memonitor, dan mengevaluasi proses pemecahan masalah saat dan sesudah pembelajaran berbasis masalah kontekstual.
\end{abstract}

Kata kunci: pembelajaran matematika, metakognisi, pendidikan dasar

\section{ABSTRACT}

This study aims to develop contextual problem based learning instruments to improve elementary school students metacognition. The process consists of define, design, and develop. The research instruments include lesson plan, worksheet, test, and questionnaire of metacognitive ability in the topic of Least Common Multiple (LCM) and Greatest Common Divisor. The data collection was conducted through expert validation, observation, questionnaire, and test. The subjects of the study were the fifth grade students of SDN Kalitengah I Tanggulangin, Sidoarjo. The findings show good quality of the developed learning instruments. More specifically, the implementation of the teaching and learning process, student activity, students metacognition learning outcome, students metacognition response, and metacognition abilit are in good category. The students metacognition show better in awareness of planning, monitoring, and evaluating problem solving process during and after contextual based learning.

Keywords: mathematics learning, metacognition, primary education.

How to Cite: Amir, M. F., \& Wardana, M. K. D. (2018). Pengembangan Perangkat Pembelajaran Berbasis Masalah Kontekstual untuk Meningkatkan Kemampuan Metakognisi Siswa Sekolah Dasar. Journal of Medives, 2 (1), 117-128. 


\section{PENDAHULUAN}

Perkembangan pendidikan matematika di tingkat sekolah dasar sampai saat ini masih menunjukkan orientasi kegiatan pembelajaran pada pemecahan masalah agar siswa memiliki kemampuan pemecahan masalah yang baik. Sebagaimana terdapat pada National Council of Teachers of Mathematics (NCTM, 2010), pemecahan masalah berperan penting dalam matematika dan kemampuan ini hendak-nya dimiliki oleh siswa mulai dari tingkat sekolah yang paling rendah. Artinya, sedini mungkin pada tingkat sekolah dasar, dalam pembelajaran matematika siswa harus dibekali dengan pemecahan masalah.

Schoenfeld (2016) menyatakan pemecahan masalah adalah sebuah proses dalam hal memahami masalah sampai pada merencanakan penyelesaian dan melaksanakannya. Kesadaran siswa dalam menyelesaikan masalah menjadi hal yang sangat penting karena melalui kesadaran ini siswa dapat mengetahui apakah proses penyelesaiannya benar dan sampai sejauh mana kebenaran tersebut, serta siswa dapat mengevaluasi letak kesalahan penyelesaiannya terdapat pada kesalahan konsep atau prosedural. Kesadaran ini, dikenal dengan istilah metakognisi.

Metakognisi termasuk dalam berpikir tingkat tinggi yang melibatkan kontrol aktif selama proses kognitif pembelajaran. Secara sederhana metakognisi didefinsikan sebagai "berpikir dalam berpikir”. Metakognisi terdiri dari dua komponen yakni pengetahuan dan pengaturan. Pengetahuan metakognitif terdiri dari pengetahuan diri sendiri sebagai siswa dan faktor-faktor yang dapat mempengaruhinya, pengetahuan tentang strategi, pengetahuan tentang kapan dan mengapa menggunakan strategi. Pengaturan metakognitif adalah pantauan seseorang tentang kognisi dan termasuk pada aktivitas perencanaan, kesadaran pemahaman dan tugas-tugas kinerja, evaluasi dari efektivitas proses, dan strategi (Lai, 2011; Ozturk, 2017).

Apabila siswa memiliki kemampuan metakognisi, siswa dapat memiliki pemahaman yang kuat dan menyeluruh pada masalah beserta solusinya dengan menggunakan argumentasi yang logis sehingga memberikan kepercayaan diri siswa dalam belajar dan memecahkan masalah (Anggo, 2011a; Barbacena \& Sy, 2015).

Pentingnya kemampuan metakognisi sebagai kompetensi dasar bagi lulusan siswa sekolah dasar di Indonesia, secara eksplisit disebutkan dalam standar kompetensi Badan Nasional Standar Pendidikan (BNSP, 2016) bahwa lulusan sekolah dasar diharapkan memiliki dimensi pengetahuan dalam hal pengetahuan faktual, konseptual, prosedural, dan metakognisi. Apabila ditinjau dari struktur pengetahuannya, maka dimensi pengetahuan faktual, konseptual, dan prosedural ada di dalam dimensi metakognisi. Artinya dapat dikatakan bahwa kemampuan metakognisi merupakan tingkat kemampuan tertinggi yang menjadi standar kompetensi lulusan di sekolah dasar.

Berdasarkan hasil observasi dan wawancara dengan guru kelas V SDN Kalitengah I Tanggulangin Sidoarjo, sebagian besar siswa selama ini kurang dapat merencanakan, memantau, dan mengevaluasi penyelesaian soal atau 
masalah matematika yang dikerjakan. Hal ini menunjukkan kemampuan metakognisi siswa masih lemah dalam menyelesaikan suatu masalah. Hasil wawancara dengan guru diperoleh bahwa guru tidak mengetahui apa itu metakognisi dan bagaimana cara meningkatkannya. Menurut Lai (2011) dan Memnun \& Akkaya (2009) menjelaskan banyak guru tidak mengetahui metode pengajaran dan cara menilai metakognisi siswa sekolah dasar, selain itu minimnya sumber belajar dan panduan mengajar bagi guru untuk meningkatkan metakognisi siswa masih menjadi kendala.

Ketersediaan perangkat pembelajaran berdasarkan masalah kontekstual dapat menjadi solusi untuk memperbaiki kemampuan metakognisi siswa. Anngo (2011b) menyebutkan dalam menyelesaikan masalah kontekstual, siswa melakukan tahap-tahap pemecahan masalah dengan membangkitkan pengetahuan yang sudah dimiliki sebelumnya berkaitan dengan konteks masalah yang selanjutnya dihubungkan dengan pengetahuan matematika formal yang dipelajari sebelumnya dapat menjadi solusi untuk mengekspolasi kemampuan metakognisi siswa.

Dari uraian di atas, perlu dikembangkan suatu perangkat pembela-jaran matematika berbasis pemecahan masalah kontekstual pada untuk mengatasi kurangnya kemampuan meta-kognisi siswa sekolah dasar.

Menurut Nugrahaningsih (2013) materi matematika salah satunya KPK dan FPB memungkinkan siswa melakukan proses metakognisi dan membuat strategi metakognitif dalam langkah-langkah pemecahannya. Oleh karena itu, materi pada perangkat pembelajaran yang dikembangkan menggunakan KPK dan FPB.

\section{METODE PENELITIAN}

Jenis penelitian ini merupakan penelitian pengembangan karena peneliti akan mengembangkan perangkat pembelajaran berbasis masalah kontekstual yang memiliki kevalidan, kepraktisan, dan keefektifan untuk meningkatkan kemampuan metakognisi siswa Sekolah Dasar. Penelitian ini dilakukan pada bulan Agustus-September 2016. Pengembangan yang dilakukan menggunakan model pengembangan "Four- $D$ Models" oleh Thiagarajan (1974), yaitu Define (Pendefinisian), Design (Perancangan), Develop (Pengembangan) dan Disseminate (Penyebaran). Tetapi pada penelitian ini hanya dibatasi sampai tahap ketiga, yaitu tahap Develop.

Tahap Define bertujuan untuk menetapkan dan mengidentifikasi pembelajaran. Kegiatan pada tahap ini meliputi analisis awal akhir, analisis siswa, analisis konsep, analisis tugas, perumusan tujuan pembelajaran.

Tahap Design bertujuan untuk menghasilkan rancangan perangkat pembelajaran berupa prototipe. Kegiatan pada tahap ini meliputi penyusunan tes, pemilihan perangkat yang dikembangkan, pemilihan format, dan desain awal.

Tahap Develop bertujuan untuk menghasilkan perangkat pembelajaran yang sudah direvisi berdasarkan masukan beberapa validator. Kegiatan pada tahap ini meliputi validasi, revisi, uji coba terbatas, analisis hasil uji coba, dan penulisan laporan. Instrumen 
penelitian yang digunakan, yaitu (1) lembar validasi, (2) lembar observasi, (3) lembar tes kemampuan metakognisi, dan (4) lembar angket metakognisi.

Perangkat dalam penelitian ini dikatakan layak merujuk pada pendapat Nieven (1999) bahwa suatu produk pembelajaran berkualitas harus memenuhi aspek valid, praktis, dan efektif. Perangkat valid jika rata-rata total lebih dari atau sama dengan 3. Perangkat praktis jika secara teori validator menyatakan bahwa RPP dan LKS yang digunakan dalam kategori revisi kecil atau tanpa revisi, termasuk kepraktisan penerapan RPP dan LKS melalui hasil pengamatan minimal dalam kategori baik atau sangat baik, serta aktivitas pembelajaran siswa dalam kategori aktif. Perangkat Efektif jika (1) Respon siswa terhadap perangkat positif. Respon siswa dikatakan posistif jika persentase respon positif siswa menunjukkan angka $70 \%$ untuk setiap pernyataan; (2) Tercapainya ketuntasan belajar metakognisi secara klasikal siswa yakni minimal $80 \%$ siswa tuntas belajar. Sedangkan siswa dikatakan tuntas ketika mereka memperoleh nilai metakognisi minimal 70 berdasarkan KKM; (3) Respon metakognisi siswa dalam kategori baik, jika minimal $80 \%$ siswa memperoleh skor angket kemampuan metakognisi minimal 10.

\section{HASIL DAN PEMBAHASAN Tahap Define}

Berdasarkan hasil observasi dan wawancara dengan guru kelas V SDN Penatarsewu Tanggulangin Sidoarjo, sebagian besar siswa selama ini kurang dapat merencanakan, memantau, dan mengevaluasi penyelesaian soal atau masalah matematika yang dikerjakan salah satunya pada materi KPK dan FPB. Misal guru memberikan soal sederhana "berapakah kelipatan persekutuan terkecil dari 2 dan 4?". Siswa kebingungan merencanakan pengetahuan awal yang dibutuhkan untuk menyelesai-kan soal. Terdapat juga siswa yang menjawab 8 dengan mengalikan 2 dan 4 , jadi siswa kurang memantau dan mengevaluasi penyelesaian karena siswa terbiasa mengalikan dua atau lebih bilangan untuk mencari kelipatan persekutuan terkecil.

Proses pembelajaran yang ada cenderung berlangsung secara teacher centered learning (berpusat pada guru). Guru membentuk kelompok-kelompok belajar, namun kelompok tidak berjalan baik dan aktif. Metode pembelajaran yang dilakukan guru tidak memperhatikan kemampuan metakognisi siswa. Yanti (2011) menyatakan bahwa aspek metakognisi saat ini kurang mendapat perhatian oleh guru dan kecenderungan pembelajaran saat ini yang menilai hasil bukan pada proses pembelajaran.

Menurut Schraw (1998) Aktivitas dalam hal merencanakan, memantau, dan mengevaluasi merupakan aktivitas esensial metakognisi. Planning (perencanaan) meliputi pemilihan strategi yang tepat dan alokasi sumber daya yang dapat mempengaruhi kinerja. Contohnya termasuk membuat prediksi sebelum membaca, urutan strategi, dan mengalokasikan waktu atau perhatian secara selektif sebelum memulai untuk mengerjakan tugas. Monitoring (Pemantauan) mengacu pada kesadaran seseorang dalam memahami tugas. Kemampuan 
untuk belajar sendiri secara periodik. Evaluation (Evaluasi) mengacu pada menilai hasil pekerjaan dan efisiensi pembelajaran seseorang. Contoh umum termasuk mengevaluasi kembali tujuan dan kesimpulan. Selain itu keterbatasan waktu guru dan kurang tersedianya perangkat pembelajaran matematika kontekstual untuk melatihkan kemampuan metakognisi siswa juga menjadi sebuah masalah. Solusi dari permasalahan tersebut yakni diperlukan suatu perangkat pembelajaran berbasis masalah kontekstual untuk meningkat-kan kemampuan metakognisi siswa sekolah dasar pada materi KPK dan FPB.

Anngo (2011b) menjelaskan pembelajaran berbasis masalah kontekstual dapat menjadi solusi untuk meningkatkan kemampuan metakognisi siswa. Rusman (2013) menjelaskan pembelajaran berdasarkan masalah membantu guru untuk menunjukkan dan memperjelas cara berpikir serta kekayaan dari struktur dan proses kognitif yang terlibat didalamnya. Pembelajaran ini mengoptimalkan tujuan, kebutuhan, motivasi yang mengarahkan suatu proses belajar yang mengakomodir kognisi pemecahan masalah. Masalah yang diberikan harus bermakna, relevan, dan kontekstual.

Analisis siswa menunjukkan bahwa siswa pernah mendapatkan materi KPK dan FPB, sehingga materi ini tidak asing bagi siswa. Dari data hasil ulangan sebelumnya diperoleh banyak siswa yang berkemampuan rendah. Hasil kemampuan metakognisi siswa sebelum diterapkan hasil pengembangan perangkat adalah 12 (80\%) dari 15 siswa memperoleh skor kurang dari 10. Hal ini menunjukkan bahwa kemampuan metakognisi siswa masih rendah. Padahal menurut Desmita (2009) pada usia 7 atau 8 tahun kemampuan metakognisi anak meningkat secara signifikan disebabkan anak semakin menyadari keinginan sadar dari pikirannya sendiri dan orang lain. Ditinjau dari kemampuan akademik siswa, kelas $\mathrm{V}$ tergolong kelas heterogen karena memiliki kemampuan akademik yang berbeda-beda yakni kemampuan tinggi, kemampuan sedang, dan kemampuan rendah.

Analisis materi bertujuan untuk mengidentifikasi poin-poin utama yang akan diajarkan serta menyusunnya secara sistematis sesuai dengan kurikulum 2006 yang berlaku. Menurut Widjaja (2013) beberapa variasi dari masalah kontekstual meliputi adaptasi masalah dari lingkungan sekitar, permainan tradisional, dan kegiatan pemodelan matematika yang melibatkan pengumpulan suatu data. Dengan demikian, hal ini mendorong peneliti untuk memberikan variasi masalah kontekstual yang sesuai dengan karakteristik siswa sekolah dasar yakni melalui aktivitas lompat kelinci pada materi KPK dan aktivitas baris berbaris pada materi FPB yang diharapkan siswa akan melakukan penyelidikan autentik (nyata) yang melibatkan pengetahuan formal dan non formal sehingga siswa dapat menemukan dan menentukan KPK dan FPB dua bilangan atau lebih.

Tahapan kognitif siswa sekolah dasar (7-12 tahun) masih dalam tahap operasi kongkrit, yang masih membutuhkan manipulasi fisik dari obyek-obyek (Hudojo 1988). Obyek-obyek tersebut dalam penelitian ini berupa ubin dan 
siswa itu sendiri. Hudojo (2005) juga menyatakan bahwa mengajar matematika di tingkat sekolah dasar harus didahului benda-benda kongkrit sehingga siswa secara bertahap melalui bekerja dan mengobservasi, siswa dengan sadar menginterprestasikan pola matematika yang terdapat pada benda kongkrit tersebut.

\section{Tahap Design}

Media yang digunakan dalam pembelajaran berdasarkan masalah kontekstual adalah ubin dan siswa itu sendiri. Pemanfaatan siswa sebagai sumber belajar atau media perantara selaras dengan pendapat Sanjaya (2013) bahwa pemanfaatan manusia sebagai sumber belajar secara langsung akan menambah motivasi belajar, menambah wawasan yang luas, dan menghindari terjadinya salah persepsi.

Format Rencana Pelaksanaan Pembelajaran (RPP) disesuaikan dengan format RPP pada kurikulum 2006. Komponen yang tercantum diantaranya satuan pendidikan, mata pelajaran, kelas, semester, alokasi waktu, materi pokok, Standar Kompetensi, Kompetensi Dasar, indikator pembelajaran, tujuan pembelajaran, materi ajar, strategi pembelajaran, langkah-langkah pembelajaran, alat dan bahan, sumber belajar, dan penilaian. Sumber belajar yang dikembangkan terdiri dari Rencana Pelaksanaan Pembelajaran (RPP), Lembar Kerja Siswa (LKS), tes hasil belajar, dan kuesioner kemampuan metakognisi.

Pada hasil perancangan awal perangkat pembelajaran dihasilkan rancangan awal yaitu RPP dan LKS untuk 3 kali pertemuan, tes hasil belajar dan kuesioner kemampuan metakognisi. Adapun indikator RPP 1 adalah (1) menjelaskan pengertian kelipatan persekutuan; (2) menentukan kelipatan persekutuan; (3) menentukan Kelipatan Persekutuan terkecil (KPK) dua bilangan atau lebih; (4) menemukan prosedur mencari KPK melalui permasalahan kontekstual. Indikator RPP 2 adalah (1) menjelaskan pengertian faktor persekutuan; (2) menentukan faktor persekutuan; (3) menentukan Faktor Persekutuan terbesar (FPB) dua bilangan atau lebih; (4) menemukan prosedur mencari FPB melalui permasalahan kontekstual. Indikator RPP 3 adalah (1) menyelesaikan masalah kontekstual KPK menggunakan faktor prima; (2) menyelesaikan masalah kontekstual FPB dalam kehidupan sehari-hari menggunakan faktor prima.

Pada tahap ini juga dirancang lembar pengamatan aktivitas siswa, lembar pengamatan keterlaksanaan pembelajaran oleh guru, dan lembar angket respon siswa terhadap pembelajaran berdasarkan masalah kontekstual. Semua hasil pada tahap perancangan ini disebut Draft 1. Setiap tahap pembelajaran berdasarkan masalah kontekstual terdapat aktivitas metakogni-si siswa dalam hal Planning (merencana-kan), Monitoring (memonitor), dan Evaluation (evaluasi),

Tes kemampuan metakognisi disusun berdasarkan analisis materi, analisis tugas, dan indikator pencapaian pembelajaran. Tes ini berbentuk uraian yang terdiri dari 3 soal. Sebelum disusun, terlebih dahulu dibuat kisi-kisi dan acuan penskoran butir soal. Tes hasil belajar metakognisi diberikan kepada 
siswa pada pertemuan pertama (pretest) dan pertemuan terakhir (postest). Kuesioner metakognisi terdiri dari 20 pernyataan dengan 2 opsi jawaban "ya" atau "tidak", kuesioner ini dikembangkan berdasarkan Tabel 1, serta menyesuaikan tingkat kognitif dan bahasa siswa sekolah dasar.

Tabel 1. Indikator Kuesioner Kemampuan Metakognitif

\begin{tabular}{|c|c|c|}
\hline $\begin{array}{c}\text { Aktivitas } \\
\text { Metakognitif }\end{array}$ & Indikator & Deskripsi \\
\hline \multirow[t]{3}{*}{ Perencanaan } & Memahami masalah & $\begin{array}{l}\text { - Memikirkan bagaimana memahami masalah } \\
\text { - Memikirkan untuk membaca masalah lebih dari } 1 \text { kali } \\
\text { - Memikirkan bagaimana mengumpulkan informasi yang } \\
\text { diketahui dan ditanyakan dari masalah yang diberikan }\end{array}$ \\
\hline & $\begin{array}{l}\text { Memikirkan representasi } \\
\text { dan mengingat kembali } \\
\text { materi prasyarat yang } \\
\text { dapat membantu } \\
\text { menyelesaikan tugas. }\end{array}$ & $\begin{array}{l}\text { - Memikirkan bagaimana memodelkan masalah dalam bentuk } \\
\text { gambar } \\
\text { - Memikirkan bagaimana memberikan keterangan notasi, } \\
\text { simbol pada pemodelan gambar } \\
\text { - Memikirkan konsep prasyarat apa sewaktu membaca soal }\end{array}$ \\
\hline & $\begin{array}{l}\text { Strategi penyelesaian yang } \\
\text { digunakan }\end{array}$ & $\begin{array}{l}\text { - Memikirkan untuk mengingat-ingat apakah pernah } \\
\text { menyelesaikan masalah ini sebelumnya } \\
\text { - Memikirkan bagaimana menyusun langkah-langkah } \\
\text { pengerjaan yang digunakan untuk menyelesaikan masalah } \\
\text { - Memikirkan strategi atau cara yang berbeda apa yang dapat } \\
\text { digunakan untuk menyelesaikan masalah. }\end{array}$ \\
\hline Memonitor & $\begin{array}{l}\text { Mengontrol } \\
\text { keterlaksanaan aktivitas } \\
\text { menyelesaikan masalah }\end{array}$ & $\begin{array}{l}\text { - Memikirkan untuk memeriksa kesesuaian notasi, simbol } \\
\text { yang digunakandari informasi yang diketahui } \\
\text { - Memikirkan untuk memeriksa kesesuaian konsep prasyarat } \\
\text { (misalkan teorema phytagoras) yang diguanakan untuk } \\
\text { menyelesaikan masalah } \\
\text { - Mengontrol kecermatan perhitungan tahap demi tahap } \\
\text { - Memikirkan untuk memeriksa setiap langkah penyelesaian } \\
\text { dan memberikan tanda cek list pada bagian yang telah } \\
\text { diperiksa. }\end{array}$ \\
\hline \multirow[t]{3}{*}{ Mengevaluasi } & $\begin{array}{l}\text { Strategi perbaikan jika } \\
\text { terdapat kesalahan }\end{array}$ & $\begin{array}{l}\text { - Memikirkan untuk mengulang kembali beberapa langkah } \\
\text { yang dikerjakan, jika menemukan kesalahan. } \\
\text { - Memikirkan untuk mencoba cara lain, jika menemukan } \\
\text { kesalahan pengerjaan. }\end{array}$ \\
\hline & $\begin{array}{l}\text { Mengevaluasi hasil yang } \\
\text { diperoleh }\end{array}$ & $\begin{array}{l}\text { - Memikirkan bagaimana cara memeriksa kesesuaian jawaban } \\
\text { dengan yang ditanyakan } \\
\text { - Memikirkan cara mengecek kembali cara yang digunakan } \\
\text { untuk memastikan jawaban sudah benar. } \\
\text { - Memikirkan kebmali apakah jawaban yang diperoleh } \\
\text { merupakan sesuatu yang baru. }\end{array}$ \\
\hline & $\begin{array}{l}\text { Mengevaluasi cara/strategi } \\
\text { yang } \\
\text { digunakan untuk } \\
\text { menyelesaikan masalah } \\
\end{array}$ & $\begin{array}{l}\text { - Memikirkan untuk menerapkan apakah cara yang digunakan } \\
\text { dapat pula digunakan untuk masalah lain } \\
\text { - Memikirkan cara lain apa yang dapat digunakan untuk } \\
\text { menyelesaikan masalah. }\end{array}$ \\
\hline
\end{tabular}

\section{Tahap Develop}

Tujuan tahap ini adalah untuk menghasilkan perangkat final yaitu perangkat pembelajaran yang sudah direvisi berdasarkan masukan para ahli (validator). Ketiga validator memberikan penilaian dengan skor 3 atau 4 pada setiap RPP, berarti komponen-komponen dalam RPP mendapatkan penilaian baik dan sangat baik. Ketiga validator menyimpulkan bahwa RPP dapat digunakan dengan sedikit revisi karena ada beberapa kalimat yang harus diperbaiki sesuai dengan tingkat berpikir 
anak sekolah dasar kelas V. Pada penilaian LKS, ketiga validator juga memberikan penilaian 3 dan 4 pada setiap LKS. Sehingga komponenkomponen dalam LKS mendapatkan penilaian kualitas baik atau sangat baik.
Untuk saran perbaikan RPP dan LKS berupa penulisan/ejaan kalimat pada naskah telah diperbaiki sesuai dengan saran validator. Cuplikan LKS final yang sudah divalidasi seperti pada Gambar 1.

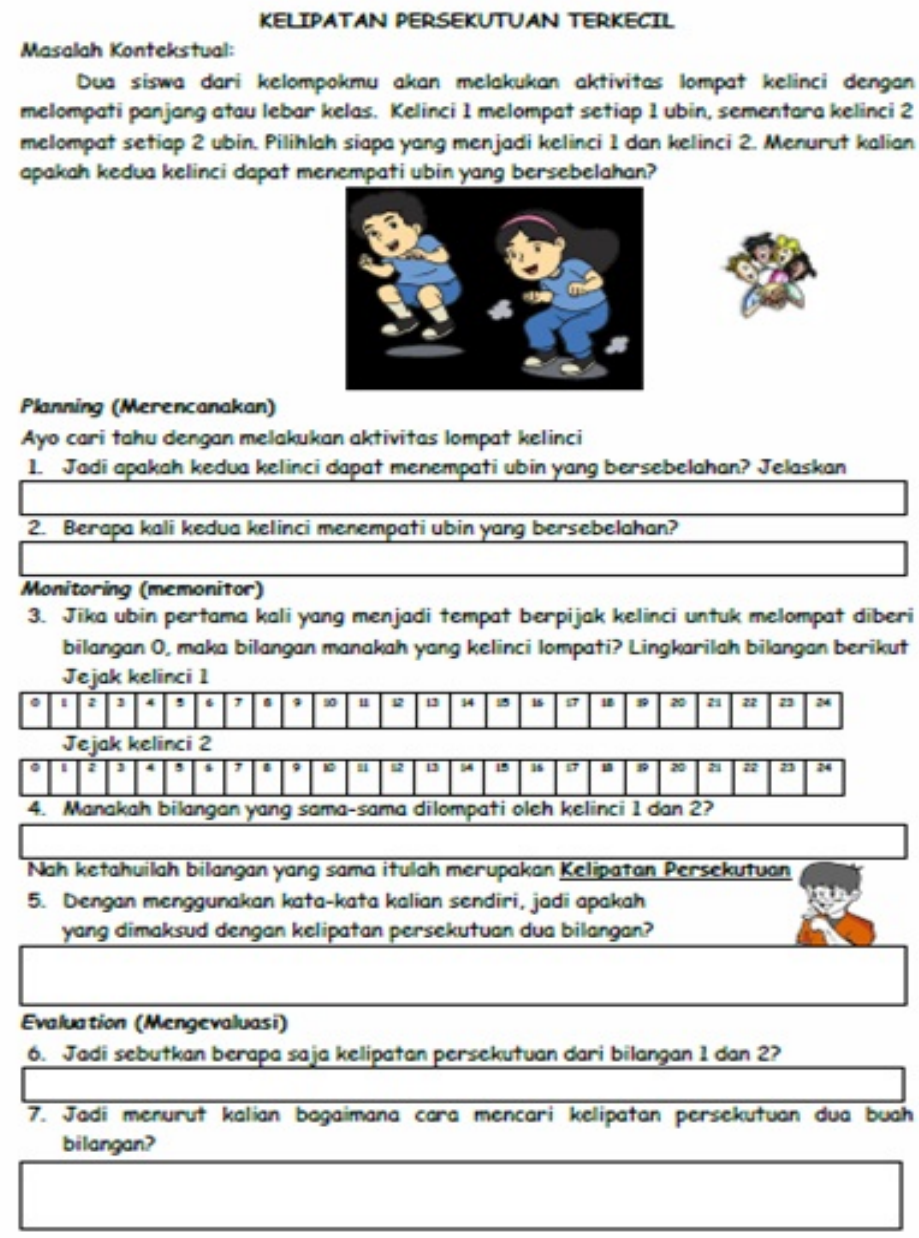

Gambar 1. Cuplikan Lembar Kerja Siswa (LKS)

Ketiga validator memberikan penilaian tes hasil belajar meliputi validitas isi, bahasa dan penulisan soal, dan rekomendasi yakni tiap butir soal berada pada kategori minimal cukup valid dan dapat dipahami. Rekomendasi dari tes ini adalah dapat digunakan dengan sedikit revisi.

Validitas kuesioner kemampuan metakognisi diketahui bahwa tiap-tiap pernyataan berada pada kategori minimal cukup valid dan bahasa dapat dipahami untuk anak sekolah dasar kelas V. Selanjutnya mengacu pada hasil validitas dan saran validator dilakukan evaluasi dan revisi.

Dalam melakukan revisi perangkat dan instrumen hasil validasi, peneliti mengacu pada hasil diskusi dengan mengikuti saran-saran serta petunjuk 
dari validator. Hasil validasi ini adalah Draft II yang selanjutnya dilakukan uji tes hasil belajar (validitas butir soal, reliabilitas soal, dan sensitivitas butir soal) dan uji keterbacaan.

Uji tes hasil belajar dilakukan diluar kelas ujicoba yakni kelas Va SDN Kalitengah 1 Tanggulangin. Uji coba ini digunakan untuk menentukan apakah tes yang dibuat perlu direvisi atau tidak. Hasil uji ini diperoleh nilai rata-rata $r_{x y}=0,68$ (tingkat validitas tinggi). Berdasarkan hasil perhitungan reliabilitas soal tes dengan menggunakan rumus alpha diperoleh koefisien reliabilitas $r_{11}(\propto)=0,39 \quad$ (kategori cukup). Hasil perhitungan sensitivitas setiap butir tes dengan menggunakan rumus indeks sensitivitas menunjukkan kemampuan butir tes dalam membedakan siswa yang belum dan sudah mendapatkan pembelajaran. Hasil indeks sensitivitas ini diperoleh rata-rata 0,66 (sensitif). Berdasarkan uji tes hasil belajar diperoleh bahwa semua butir soal tes hasil belajar dapat digunakan tanpa revisi untuk mengukur penguasaan siswa terhadap materi KPK dan FPB.

Uji keterbacaan terhadap Draft II dilakukan terhadap 6 siswa kelas $\mathrm{Va}$ SDN Kalitengah I Tanggulangin Sidoarjo. Hasil analisis uji keterbacaan menunjukkan bahwa LKS sebagai perangkat pembelajaran dapat terbaca dengan jelas, dapat dipahami oleh siswa, dan tampilan LKS menarik. Dengan demikian LKS yang dikembangkan tidak perlu direvisi dan dapat digunakan di kelas uji coba.

Berdasarkan dari analisis di atas, Draft II merupakan perangkat pembelajaran yang telah diperbaiki berdasarkan masukan dan saran dari para validator dan sudah dilakukan uji keterbacaan dan uji validitas dan reliabilitas soal tes hasil belajar. Selanjutnya diujicobakan di kelas Vb SDN Kalitengah I Tanggulangin Sidoarjo. Di kelas uji coba dilaksanakan 5 kali pertemuan yaitu pretest, uji coba perangkat 1 , uji coba perangkat 2 , uji coba perangkat 3 , dan posttest. Uji coba ini dilakukan guru mitra dan melibatkan 4 orang pengamat yang bertugas 1 orang mengamati aktivitas guru dan 3 orang mengamati aktivitas siswa.

Dari hasil ujicoba perangkat pembelajaran, diperoleh data hasil pengamatan keterlaksanaan kegiatan pembelajaran, data hasil pengamatan aktivitas siswa, data pretest, dan posttest, data kemampuan metakognisi siswa dan data respon siswa. Data yang diperoleh saat ujicoba dianalisis, kemudian hasilnya digunakan sebagai bahan pertimbangan untuk merevisi draft II menjadi perangkat pembelajaran yang valid, praktis, dan efektif.

Setiap aspek keterlaksanaan kegiatan pembelajaran oleh guru pada setiap pertemuan, termasuk dalam kategori cukup baik atau baik. Beberapa diantara aktivitas yang dilakukan guru adalah (1) menyampaikan tujuan pembelajaran; (2) melatihkan siswa kemampuan metakognisi dalam hal planning, monitoring, dan evaluation melalui masalah kontekstual; kegiatan belajar mengajar berpusat pada aktivitas siswa. Hal ini menunjukkan bahwa pembelajaran dapat digunakan dengan baik oleh guru sehingga perangkat tidak perlu direvisi. 
Berdasarkan kriteria aktivitas siswa, setiap aspek rencana pelaksanaan pembelajaran terlaksana dan berada dalam interval penentuan waktu ideal. Aktivitas siswa secara keseluruhan menunjukkan siswa aktif dan kegiatan berorientasi untuk melatihkan kemampuan metakognisi.

Sejalan dengan penelitian Fariana (2017) bahwa peningkatan aktivitas siswa dikarenakan pengelolaan kelas yang dilakukan oleh guru semakin membaik karena akan berkaitan langsung dengan proses pembelajaran. Untuk menyelesaikan masalah kontekstual, siswa melakukan rencana (planning) dengan cara berdiskusi, mengontrol langkah-langkah pemecahan masalah (monitoring) dengan cara memeriksa kesesuaian konsep prasyarat yang digunakan, lalu mengevaluasi (evaluation) proses pemecahan masalah secara keseluruhan. Munculnya aktivitas metakognisi tersebut dalam memecahkan masalah sesuai dengan pendapat Anggo (2011a) bahwa aktivitas proses metakognisi siswa dalam planning, monitoring, dan evaluation muncul saat memecahkan masalah kontekstual.

Respons siswa terhadap semua aspek berada di atas 70\%, artinya aspekaspek perangkat pembelajaran tersebut direspons positif oleh siswa dan proses pembelajaran dikatakan efektif. Ratarata ketuntasan belajar siswa adalah $81 \%$, oleh karena itu ditinjau dari aspek ketuntasan belajar siswa dengan kriteria bahwa aspek ketercapaian tingkat ketuntasan belajar yakni minimal $80 \%$ siswa mencapai penguasaan bahan ajar minimal 70 (mencapai skor 70 untuk rentang skor 0-100). Berdasarkan data kriteria kemampuan metakognisi siswa termasuk dalam kategori baik dimana minimal $80 \%$ siswa mencapai skor minimal 10 (rentang 0-20). Hal ini senada dengan Waters (2010) bahwa kemampuan metakognisi siswa sekolah dasar dapat dilatih dengan menghubungkan antara apa yg dilakukan dengan kesadaran beserta konsekeunsi tindakannya baik kegiatan di dalam atau diluar kelas.

Berdasarkan uraian tentang hasil uji coba perangkat pembelajaran, dapat disimpulkan bahwa perangkat pembelajaran model pembelajaran berdasarkan masalah kontekstual untuk melatih dan meningkatkan kemampuan metakognisi siswa kelas V SD pada materi KPK dan FPB yang dikembangkan memenuhi kriteria yang baik. Proses aktivitas siswa dalam pembelajaran berbasis masalah kontekstual menunjukkan kesadaran siswa dalam merencakan (planning) penyelesaian suatu masalah melalui diskusi kelompok, lalu mengontrol (monitoring) langkah-langkah pemecahan masalah dengan cara memeriksa kesesuaian konsep prasyarat yang digunakan, dan mengevaluasi (evaluation) keseluruhan proses pemecahan masalah dan temuan ini sesuai dengan hasil penelitian Millis (2016) bahwa pembelajaran yang menekankan pada kesadaran diri siswa selama proses pembelajaran akan meningkatkan kemampuan metakognisi siswa.

\section{PENUTUP}

Berdasarkan hasil dan pembahasan penelitian diperoleh simpulan bahwa perangkat pembelajaran berbasis masalah kontekstual untuk meningkat- 
kan kemampuan metakognisi siswa sekolah dasar berkualitas baik. Hal ini ditunjukkan oleh (1) perangkat pembelajaran dinyatakan valid atau berkualitas baik berdasarkan penilaian vaidator; (2) perangkat pembelajaran dinyatakan praktis berdasarkan hasil pengamatan keterlaksanaan pembelajaran oleh guru dan aktivitas siswa dalam pembelajaran dinyatakan baik; (3) perangkat pembelajaran dinyatakan efektif berdasarkan respon positif siswa terhadap perangkat pembelajaran yakni lebih dari $70 \%$ ketuntasan belajar metakognisi siswa sebesar $81 \%$, dan secara keseluruhan kemampuan metakognisi siswa berkategori baik; (4) fase-fase pembelajaran berbasis masalah kontekstual dapat melatihkan kemampuan metakognisi sehingga dapat meningkatkan kemampuan metakognisi siswa sekolah dasar; (5) Kemampuan metakognisi siswa selama dan setelah diterapkan pembelajaran berbasis masalah kontekstual menunjukkan kesadaran pemecahan masalah dalam hal merencanakan (planning), mengontrol (monitoring), dan mengevaluasi (evaluation) proses pemecahan masalah yang lebih baik.

\section{DAFTAR PUSTAKA}

Anggo, M. (2011a). Pelibatan Metakognisi Dalam Pemecahan Masalah Matematika. Edumatica: Jurnal Pendidikan Matematika. 1(1), 25-32.

Anggo, M. (2011b). Pemecahan Masalah Matematika Kontekstual untuk Meningkatkan Kemampuan Metakognisi Siswa. Edumatica: Jurnal Pendidikan Matematika. 1(2), 35-42.
Barbacena, L. B., \& Sy, N. R. (2015). Metacognitive Model in Mathematical Problem Solving. BU Faculty e-Journal, 12(1), 1622.

BNSP. (2016). Lampiran Peraturan Menteri Pendidikan dan Kebudayaan Nomor 20 Tahun 2016 Tentang Standar Kompetensi Lulusan Pendidikan Dasar dan Menengah. Jakarta: Depdiknas.

Desmita. (2009). Psikologi Perkembangan Peserta Didik. Bandung: PT Remaja Rosdakarya.

Fariana, M. (2017). Implementasi Model Problem Based Learning Untuk Meningkatkan Pemahaman Konsep dan Aktivitas Siswa. Journal Of Medives, 1(1), 25-33.

Hudojo, H. (1988). Mengajar belajar matematika. Jakarta: Depdikbud.

Hudojo, H. (2005). Pengembangan Kurikulum dan Pembelajaran Matematika. Malang: Universitas Negeri Malang.

Lai, E. R. (2011). Metacognition: A Literature Review. Pearson's Research Reports on April.

Memnun, D. S., \& Akkaya, R. (2009). The levels of metacognitive awareness of primary teacher trainees. Procedia-Social and Behavioral Sciences, 1(1), 19191923.

Millis, B. J. (2016). Using Metacognition to Promote Learning. IDEA Paper. 63, December, 1-9.

NCTM. (2010). Why is Teaching with Problem Solving Important to Student Learning? National Council of Teachers of Mathematics, 13(12), 1-6. 
Nieveen, N., Gustafson, K., Branch, R. M., \& van den Akker, J. 1999. Design approaches and tools in education and training. Dordrecht: ICO Cluwer academic publisher.

Nugrahaningsih, T. K. (2013). Pengembangan Materi Pembelajaran Matematika SD Berbasis Metakognisi Yang Bermuatan Karakter. Konferensi Nasional Pendidikan Matematika $V$. Malang: Universitas Negeri Malang.

Ozturk, N. (2017). Assessing Metacognition: Theory and Practices. International Journal of Assessment Tools in Education (IJATE), 4(2), 134-148.

Rusman. (2014). Penerapan Pembelajaran Berbasis Masalah. Edutech, 1(2), 211-230.

Sanjaya, Wina. (2013). Strategi Pembelajaran: Berorientasi Standar Proses Pendidikan. Jakarta: Kencana Prenadamedia Group.

Schoenfeld, A. H. (2016). Learning to Think Mathematically: Problem Solving, Metacognition, and Sense Making in Mathematics (Reprint). Journal of Education, 196(2), 138.
Schraw, G., \& Dennison, R. S. (1994). Assessing metacognitive awareness. Contemporary educational psychology, 19(4), 460-475.

Schraw, G., (1998). Promoting general Metacognitive Awareness a Framework for Understanding Metacognition. Instructional Science, 26, 113-125.

Thiagarajan, S. (1974). Instructional Development for Training Teachers of Exceptional Children. A Sourcebook. Indiana: University Bloomington.

Waters, H. S. (2010). Metacognition, Strategy Use, \& Instruction. New York: The Guilford Press.

Widjaja, W., (2013). The use of contextual problems to support mathematical learning. Mathematical Society Journal on Mathematic, 4(2), 151-159.

Yanti, A.W. (2011). Learning Mathematics To Grow Metacognitive Ability In Understanding And Mathematic Problems Solving On Limit. Proceedings International Seminar and the Fourth National Conference on Mathematics Education. Department of Mathematics Education, Yogyakarta State University. 